\title{
Prochlorococcus growth rate and contribution to primary production in the equatorial and subtropical North Pacific Ocean
}

\author{
Hongbin Liu*, Hector A. Nolla, Lisa Campbell** \\ Department oi Oceanography, School of Ocean and Earth Science and Technology, University of Hawaii, 1000 Pope Road, \\ Honolulu, Hawaii 96822, USA
}

\begin{abstract}
DNA synthesis and cell division of Prochlorococcus are tightly synchronized to the daily light cycle, therefore, cell division rates can be estimated from the fraction of cells in each cell cycle stage during a $24 \mathrm{~h}$ sampling period. The total mortality rate of Prochlorococcus can also be estimated from the difference between the observed cell abundance and the expected cell number projected from. growth rate in that sampling period, providing an estimate of grazing impact. Growth and mortality rates of Prochlorococcus were investigated at 2 stations in the equatorial Pacific, as well as Station ALOHA in the subtropical North Pacific Ocean. Growth rate of Prochlorococcus remained high at all sites independent of the nitrate concentration. The maximum growth rate (up to 1 doubling $\mathrm{d}^{-1}$ ) occurred at $70 \mathrm{~m}$ depth at the western equatorial Pacific site $\left(166^{\circ} \mathrm{E}\right)$ and at 40 to $45 \mathrm{~m}$ at the eastern equatorial Pacific site $\left(150^{\circ} \mathrm{W}\right)$ and at Station ALOHA $\left(22^{\circ} 45^{\prime} \mathrm{N}, 158^{\circ} \mathrm{W}\right)$. Total mortality rates were roughly balanced by Prochlorococcus growth at all stations. Because of the phased cell cycle and continuous (if not evenly distributed) mortality, the abundance of Prochlorococcus at each depth could vary up to 2 -fold between afternoon and midnight. Prochlorococcus production was estimated to contribute 9 and $39 \%$ to the total gross primary production in the eastern and western equatorial Pacific, respectively, and up to $82 \%$ in the subtropical North Pacific Ocean at Station ALOHA. Our results suggest Prochlorococcus are not severely nutrient-limited in the oligotrophic environment. Rapid nutrient recycling by grazing activity permits Prochlorococcus to contribute a significant fraction of the total primary production.
\end{abstract}

KEY WORDS: Prochlorococcus - Cell cycle Growth Grazing Production. Pacific Ocean . Flow cytometry

\section{INTRODUCTION}

Picophytoplankton, including Prochlorococcus, Synechococcus and picoeucaryotes $(<2 \mu \mathrm{m})$, is the dominant contributor to biomass and primary production in the subtropical and tropical ocean (Li et al. 1983, Platt et al. 1983, Peña et al. 1990, Le Bouteiller et al. 1992, Campbell et al. 1994). Recent studies indicate that picoeucaryotes dominate the biomass and productivity of picophytoplankton in most regions of the world ocean (see Li 1995), except the central North Pacific

\footnotetext{
•E-mail: hliu@soest.hawaii.edu

- Present address and address for offprint requests: Department of Oceanography, Texas A\&M University, College Station, Texas 77843-3146, USA
}

where Prochlorococcus accounted for $64 \%$ of biomass (Campbell et al. 1994) and up to $44 \%$ of gross primary production (Vaulot 1995). The grazing of heterotrophic flagellates and ciliates on Prochlorococcus and other picoplankters is substantial. Mortality due to grazing is essentially equivalent to the growth of picophytoplankton and probably controls the temporal variation of the phytoplankton population (Banse 1992, Cullen et al. 1992, Landry et al. 1995, Liu H. et al. 1995). Existing methods for estimating population-specific growth and grazing rates include the dilution (Landry \& Hassett 1982) and selective metabolic inhibitor (Fuhrman \& McManus 1984) techniques. These methods have the same disadvantage, i.e. they each use long-term (usually $24 \mathrm{~h}$ ) incubation which can be a major source of uncertainty. Apart from the bottle effect, metal con- 
tamination can be introduced during sampling and handling procedures (Fitzwater et al. 1982). Serious error can also be caused by the inability to mimic the intensity and spectral characteristics of submarine light properly (Laws et al. 1990, McManus 1995).

Two prokaryotic cell cycle models, the fast growth and the slow growth, have been proposed (Cooper \& Helmstetter 1968). In fast-growing prokaryotes, DNA synthesis is usually continuous during the whole cell cycle and the resulting DNA histograms are unimodal or multimodal. The slow growth case applies when the generation time of the cells is less than the sum of the time required for DNA replication and the time between the termination of replication and cell division. Consequently, the resulting DNA frequency distributions are bimodal. The first peak corresponds to cells in $G_{1}$ (prior to the start of chromosome replication), the second peak corresponds to cells in $\mathrm{G}_{2}$ (those having finished DNA replication but not yet divided), and the intermediate part of the distribution corresponds to the cells in $S$ (those in the midst of DNA replication). The observation of bimodal DNA histograms and synchronous cell-division in Prochlorococcus (Vaulot \& Partensky 1992, Vaulot et al. 1995) permits growth rate estimates of in situ Prochlorococcus populations to be made based on the fraction of cells in each cell cycle stage during a $24 \mathrm{~h}$ sampling period (Carpenter \& Chang 1988). Estimation of growth rate with this approach thus avoids errors introduced by incubation. Because this estimate of growth rate is independent of grazing impact and other losses, the total mortality rate of Prochlorococcus can also be calculated from the difference between the observed cell abundance and the cell number projected from growth rate in that sampling period. We used the diel cell cycle approach at time-series stations in the equatorial Pacific $\left(166^{\circ} \mathrm{E}\right.$ and $\left.150^{\circ} \mathrm{W}\right)$ and at $\sim 100 \mathrm{~km}$ north of Oahu, Hawaii, USA, at Station ALOHA $\left(22^{\circ} 45^{\prime} \mathrm{N}\right.$, $158^{\circ} \mathrm{W}$ ) to investigate the growth and mortality rates of Prochlorococcus and its contribution to primary production.

\section{MATERIALS AND METHODS}

Samples were collected from 2 equatorial time-series stations $\left(166^{\circ} \mathrm{E}\right.$ and $150^{\circ} \mathrm{W}$, hereafter referred to as W-EqPac and E-EqPac, respectively) during the French JGOFS FLUPAC cruise in October 1994 and during 2 cruises in the subtropical North Pacific at Station ALOHA $\left(22^{\circ} 45^{\prime} \mathrm{N}, 158^{\circ} \mathrm{W}\right)$ in September 1993 and July 1994 (HOT49 and HOT55, hereafter referred to as ALOHA Sept 93 and ALOHA July 94, respectively). Using Niskin bottles mounted on a CTD rosette, 9 depths throughout the $150 \mathrm{~m}$ euphotic zone were sampled at frequent intervals over a $24 \mathrm{~h}$ period Although the time interval between sampling varied from 1.5 to $5 \mathrm{~h}$, the most frequent sampling took place from noon through midnight because Prochlorococcus DNA synthesis and cell division occurs during this period (Vaulot et al. 1995). Samples (1 ml) were preserved with $0.2 \%$ (final concentration) paraformaldehyde in cryovials, quickly frozen in liquid nitrogen and stored at $-80^{\circ} \mathrm{C}$ until flow cytometric analysis

Samples were analyzed upon return to the laboratory using a Coulter EPICS 753 flow cytometer equipped with two $5 \mathrm{~W}$ argon lasers and an MSDS automatic sampler. The flow cytometer was set up for UV $(225 \mathrm{~mW})$ and $488 \mathrm{~nm}(1 \mathrm{~W})$ colinear analysis. Hoechst 33342 (DNA-specific fluorochrome) was added to thawed sample at a final concentration of $1 \mu \mathrm{g} \mathrm{ml}^{-1}$ and incubated for $1 \mathrm{~h}$ at room temperature in the dark. To achieve a better coefficient of variation (CV) for fluorescence, a slower delivery rate $\left(10 \mu \mathrm{l}^{-1}\right)$ was used. $C V$ 's for both $G_{1}$ and $G_{2}$ peaks ranged from 6 to $8 \%$ for the Prochlorococcus from the upper $100 \mathrm{~m}$ of the water column and were not greater than $10 \%$ for those from the bottom of the euphotic zone at all locations. For statistical purposes, 100 to $300 \mu \mathrm{l}$ of samples was analyzed to collect more than 10000 events of a gated Prochlorococcus population, except for the samples below $125 \mathrm{~m}$ which contained fewer Prochlorococcus, making 10000 counts impractical. Six parameters (log integrated chlorophyll and DNA fluorescence, forward and $90^{\circ}$ light scatter signals, linear integrated and peak DNA fluorescence) were collected in list mode for Prochlorococcus and analysed using the CYTOPC software (Vaulot 1989)

The Prochlorococcus cell cycle is analagous to the eucaryotic cell cycle. It exhibits a bimodal DNA distribution, i.e. DNA histograms display 2 peaks corresponding to the initial growth phase, $G_{1}$, and the late growth phase, $G_{2}$, separated by a discrete DNA synthesis phase S (Vaulot \& Partensky 1992). One-parameter histogram files containing the DNA fluorescence data for Prochlorococcus were analyzed using MCYCLE software (Phoenix Flow Systems, San Diego, CA, USA) and cell fractions in $G_{1}, S$ and $G_{2}$ phases were computed from DNA distributions. The combination of the $S$ and $G_{2}$ phases was chosen as the terminal phase and its duration $\left(t_{\mathrm{S}+\mathrm{G}_{2}}\right)$ was computed as twice the distance between the peak of cells in $S$ and the peak of cells in $\mathrm{G}_{2}$ (Carpenter \& Chang 1988). Because the distance between the 2 peaks is obviously affected by the time interval between sampling, the inaccuracy in the estimation of $t_{\mathrm{S}+\mathrm{G}_{2}}$ is the major source of error for the growth rate calculation. Since hourly CTD casts were not possible, our solution was to collect surface bucket samples more frequently, i.e. every hour during Prochlorococcus DNA replication and cell division 
(15:00 to 24:00 h local time). Results from 2 successive days verified a $3 \mathrm{~h}$ distance from the peak of $\mathrm{S}$ to the peak of $\mathrm{G}_{2}$ (Fig 1). An average $t_{\mathrm{S}+\mathrm{G}_{2}}$ of $6 \mathrm{~h}$ was used for Prochlorococcus in the upper $100 \mathrm{~m}$ in our calculation, which is the same time period used by Vaulot et al. (1995). Because $t_{\mathrm{S}+\mathrm{C}_{2}}$ tended to be longer for the Prochlorococcus living under very low light intensity. observed time interval between the peaks of cells in $S$ and $G_{2}$ phases was used for samples taken below $100 \mathrm{~m}$.

Growth rate $\left(\mu_{i} \mathrm{~d}^{-1}\right)$ was computed as

$$
\mu=\frac{1}{t_{\mathrm{S}+\mathrm{G}_{2}}} \int_{0}^{24} \ln \left[1+f_{\mathrm{S}+\mathrm{G}_{2}}(t)\right]
$$

where $f_{S+G_{2}}(t)$ is the fraction of cells in $S+G_{2}$ at time point $t$ in the $24 \mathrm{~h}$ sampling period. The formula described in Vaulot et al. (1995), a modification of McDuff \& Chisholm (1982), is only valid when all cells have the same duration of a terminal event, $t_{\mathrm{d}}$, and requires fixed sampling intervals (Vaulot 1992). It will dramatically overestimate the division rate if samples are taken more frequently during the high $S$ and $G_{2}$ period. The formula we used here computes the area under the percentage curve of $\mathrm{S}+\mathrm{G}_{2}$ and, therefore, is not affected by the change in sampling frequency.

Integrated division rates $\left(\mu_{\mathrm{int}}\right)$ in the upper $150 \mathrm{~m}$ of the water column were computed as

$$
\mu_{\text {int }}=\ln \left[\int N_{\text {initial }}(z) \mathrm{e}^{\mu(z)} \mathrm{d} z / \int N_{\text {initual }}(z) \mathrm{d} z\right]
$$

where $z$ is the water column depth; $\mu(z)$ is the growth rate calculated from Eq. (1) and $N_{\text {initial }}$ is the cell concentration just before division (from 16:00 h for the deep layer to as late as 20:00 h for surface samples). This approach weights division rates by cell concentrations just before division and is more accurate than a simple depth-averaged rate.

We calculated Prochlorococcus mortality rates ( $m$, $d^{-1}$ ) from

$$
m=-\ln \left(N_{24} / N_{0}\right)+\mu
$$

where $N_{0}$ and $N_{24}$ are the concentration of Prochlorococcus at the beginning and end of the $24 \mathrm{~h}$ sampling period, respectively. The mortality rate estimated from Eq. (3) is based on the assumption that other loss terms, such as sinking and advection, are negligible and the effect of patchy distribution does not exist at the sampling site. Assuming we were sampling the same waters during the entire $24 \mathrm{~h}$ sampling period, the integrated mortality rates $\left(m_{\text {int }}\right)$ in upper $150 \mathrm{~m}$ of the water column were calculated from

$$
m_{\mathrm{in} 1}=-\ln \left[\int N_{24}(z) \mathrm{d} z / \int N_{0}(z) \mathrm{d} z\right]+\mu_{\mathrm{int}}
$$

Depth-integrated carbon production ( $\mathrm{mg} \mathrm{C} \mathrm{m} \mathrm{C}^{-2} \mathrm{~d}^{-1}$ ) of Prochlorococcus was computed using the carbon conversion factors from Campbell et al. (1994). Total

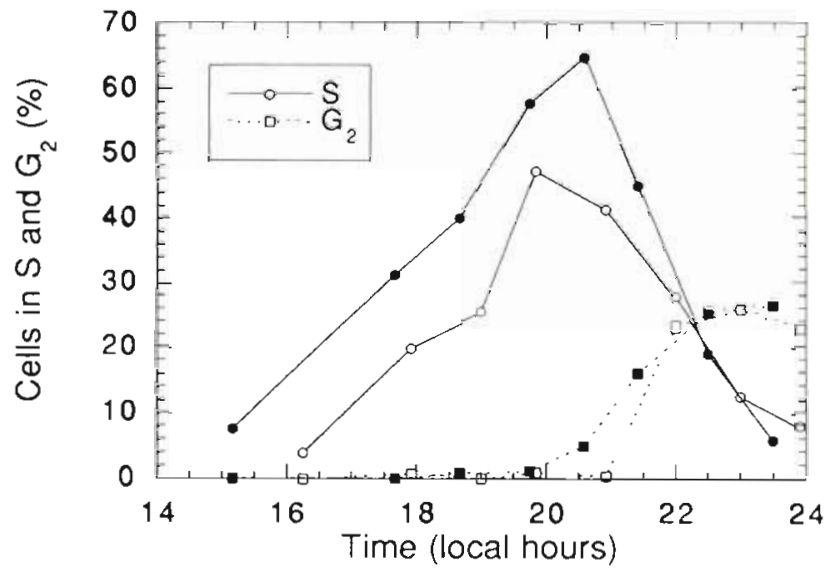

Fig. 1. Percentage of Prochlorococcus cells in S (circles) and $\mathrm{G}_{2}$ (squares) phases for the samples taken from the surface waters of Station ALOHA $\left(22^{\circ} 45^{\circ} \mathrm{N}, 158^{\circ} \mathrm{W}\right)$ on July 29 $(\mathrm{O}, \mathrm{\square})$ and July $30(\bullet, \mathbf{\bullet}), 1995$

gross primary production was converted from ${ }^{14} \mathrm{C}$ data by multiplying by 1.55 (Bender et al. 1992) to account for the fraction of Prochlorococcus contribution.

\section{RESULTS AND DISCUSSION}

The western equatorial Pacific (W-EqPac $166^{\circ} \mathrm{E}$ ) is an oligotrophic environment with a high temperature $\left(-30^{\circ} \mathrm{C}\right)$, low salinity $(-33.9 \mathrm{psu})$ surface mixed layer extending to $-90 \mathrm{~m}$. Nitrate and nitrite were not detectable above the thermocline and a strong, deep $(90 \mathrm{~m})$ chlorophyll maximum coincided with the nitracline (Le Borgne et al. 1995). The eastern equatorial Pacific (E-EqPac; $150^{\circ} \mathrm{W}$ ) is a mesotrophic habitat featuring measurable nutrients and higher primary production in the surface mixed layer. However, during our investigation, the existence of a deep surface mixed layer $(\sim 100 \mathrm{~m})$ suggested developing El Niño conditions (Barber \& Chavez 1983, Liu W. T. et al. 1995). The abundance of Prochlorococcus at W-EqPac was about twice as high as that in E-EqPac (Fig. 2). However, the abundance of other picophytoplankton, i.e. Synechococcus and picoeucaryotes, was significantly higher at E-EqPac (Le Borgne et al. 1995). As representative of the oligotrophic North Pacific subtropical gyre, Station ALOHA is characterized by a nutrient-depleted surface mixed layer and a low standing stock of organisms and primary production (Karl et al. 1995). Prochlorococcus dominates the picophytoplankton biomass with an average depth-integrated abundance of about $2 \times 10^{9}$ cells $\mathrm{cm}^{-2}$ (Campbell \& Vaulot 1993) that varies 2 -fold annually with a maximum in summer which usually coincides with a deeper nitracline and shallower mixed layer (Campbell et al. 


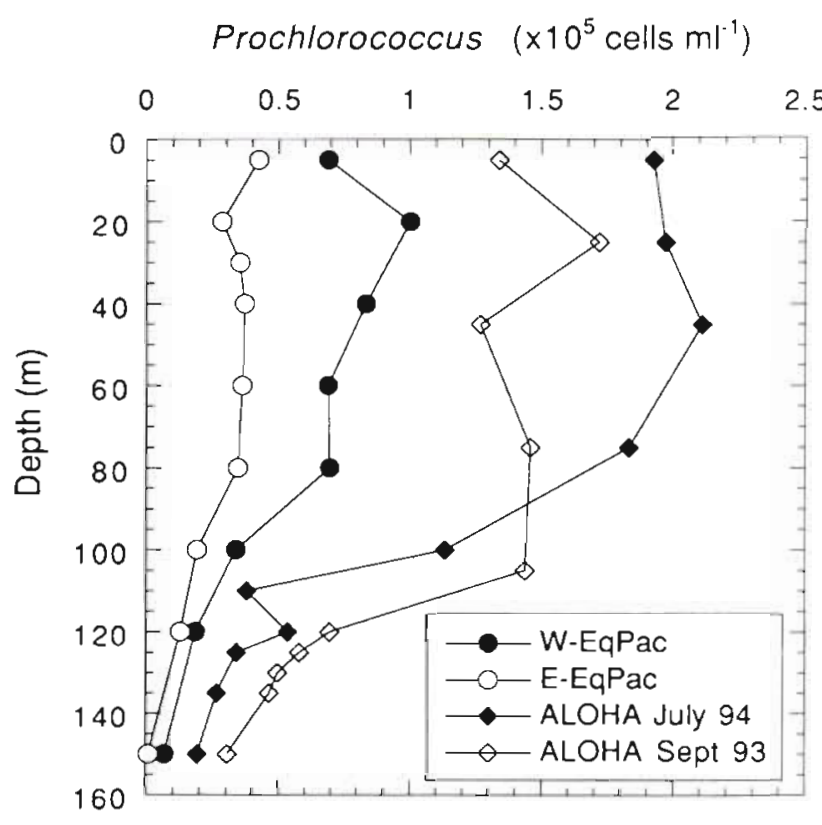

Fig. 2. Vertical profile of Prochlorococcus cell concentrations at $W$-EqPac $\left(0^{\circ}, 166^{\circ} \mathrm{E}\right)$ and E-EqPac $\left(0^{\circ}, 150^{\circ} \mathrm{W}\right)$ stations in October 1994 and in the subtropical North Pacific Ocean at Station ALOHA $\left(22^{\circ} 45^{\prime} \mathrm{N}, 158^{\circ} \mathrm{W}\right)$ in September 1993 (HOT49) and July 1994 (HOT55). Data shown here are Prochlorococcus cell concentrations just before cell division $(-16: 00 \mathrm{~h}$, local time $)$
1996). Our investigation was conducted during summer when the mixed-layer depth was 24 to $41 \mathrm{~m}$ and the nitracline was $-125 \mathrm{~m}$ (Table 1). The vertical profiles of Prochlorococcus cell concentrations at cach station show a subsurface peak at all stations except $E$ EqPac (Fig. 2).

We observed a diel DNA distribution pattern similar to the previous report by Vaulot et al. (1995) at both locations. In the relatively nutrient-rich water at E-EqPac, cells began to enter the $S$ phase between $11: 30$ and $13: 30 \mathrm{~h}$ and the $G_{2}$ phases between 16:00 and $17: 30 \mathrm{~h}$, at $20 \mathrm{~m}$ and below. Phasing was delayed by about $2.5 \mathrm{~h}$ in the surface waters. At the oligotrophic W-EqPac Station, this delay extended to $40 \mathrm{~m}$, possibly because of the deeper euphotic zone. At Station ALOHA, the starting time for both $\mathrm{S}$ and $\mathrm{G}_{2}$ phases in the upper and lower euphotic layer were further delayed by 1 to $2 \mathrm{~h}$. No cells in the surface waters entered the $\mathrm{S}$ phase until sunset. The delay in the surface water may be a protective mechanism for avoiding high irradiance as proposed by Vaulot et al. (1995).

The estimated Prochlorococcus growth rates for all stations are shown in Fig. 3. Maximum growth rate ranged from 0.64 to $0.78 \mathrm{~d}^{-1}$, but occurred at different depths. Maximum growth rate occurred at $70 \mathrm{~m}$ at the oligotrophic W-EqPac Station, $40 \mathrm{~m}$ at the mesotrophic E-EqPac, and $45 \mathrm{~m}$ at Station ALOHA during both cruises. The difference between these stations may be

Table 1 A comparison of Prochlorococcus cell concentration, growth and mortality rates, carbon production and contribution to the total primary production. All depth-integrated data are for the upper $150 \mathrm{~m}$ of the water column

\begin{tabular}{|c|c|c|c|c|}
\hline Region & \multicolumn{2}{|c|}{ Equatorial Pacific } & \multirow{2}{*}{\multicolumn{2}{|c|}{$\begin{array}{c}\text { Subtropical North Pacific } \\
\text { ALOHA }\end{array}$}} \\
\hline Station & Western & Eastern & & \\
\hline Location & $0^{\circ}, 167^{\circ} \mathrm{E}$ & $0^{\circ}, 150^{\circ} \mathrm{W}$ & \multicolumn{2}{|c|}{$22^{\circ} 45^{\prime} \mathrm{N}, 158^{\circ} \mathrm{W}$} \\
\hline Cruise & FLUPAC & FLUPAC & HOT49 & HOT55 \\
\hline Date & Oct 1994 & Oct 1994 & Sept 1993 & Jul 1994 \\
\hline Environment & Oligotrophic & Mesotrophic & Oligotrophic & Oligotrophic \\
\hline Surface $\mathrm{NO}_{3}$ concentration $(\mu \mathrm{M})^{\mathrm{d}}$ & 0 & 2.8 & 0 & 0 \\
\hline Nitracline depth $(\mathrm{m})^{d}$ & 90 & & 126 & 125 \\
\hline Integrated $\mathrm{NO}_{3}$ conc. $\left(\mu \mathrm{mol} \mathrm{cm} \mathrm{cm}^{-2}\right)$ & 57 & 92 & 5.3 & 2.8 \\
\hline Integrated chl a conc $\left(\mathrm{mg} \mathrm{m}^{-2}\right)^{\mathrm{d}}$ & 25.2 & 28.6 & 19.1 & 22.8 \\
\hline \multicolumn{5}{|l|}{ Integrated Prochlorococcus abundance $\left(\mathrm{cm}^{-2}\right)$} \\
\hline Minimum & $8.35 \times 10^{8}$ & $3.97 \times 10^{8}$ & $1.63 \times 10^{9}$ & $1.95 \times 10^{9}$ \\
\hline Maximum & $1.15 \times 10^{9}$ & $6.74 \times 10^{9}$ & $2.16 \times 10^{9}$ & $2.61 \times 10^{9}$ \\
\hline Integrated growth rates $\left(\mathrm{d}^{-1}\right)$ & 0.61 & 0.60 & 0.53 & 0.57 \\
\hline Depth of maximum $\mu(\mathrm{m})$ & 70 & 40 & 45 & 45 \\
\hline Integrated mortality rates $\left(\mathrm{d}^{-1}\right)$ & 0.59 & 0.47 & 0.45 & 0.54 \\
\hline Integrated Prochlorococcus production ( $\mathrm{mg} \mathrm{C} \mathrm{m} \mathrm{C}^{-2} \mathrm{~d}^{-1}$ ) & 409 & 183 & 620 & 743 \\
\hline \multicolumn{5}{|l|}{ Integrated total primary production $\left(\mathrm{mg} \mathrm{C} \mathrm{m}^{-2} \mathrm{~d}^{-1}\right)$} \\
\hline${ }^{14} \mathrm{C}^{\mathrm{a}}$ & 670 & 1330 & 541 & 584 \\
\hline Gross & 1039 & 2062 & 839 & 905 \\
\hline Prochlorococcus contribution to gross carbon production $(\%$ & \%) 39 & 9 & 74 & 82 \\
\hline
\end{tabular}




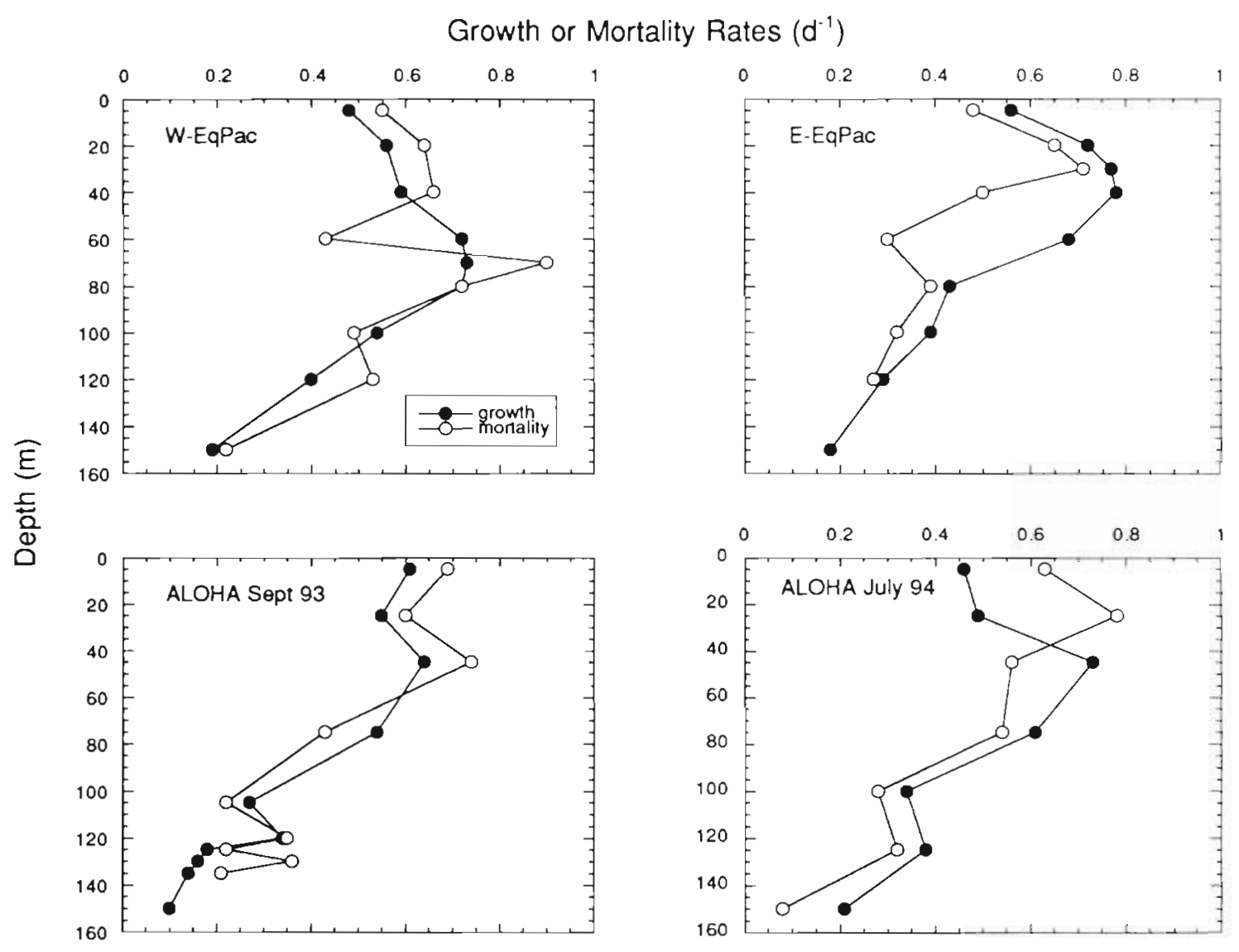

Fig. 3. Prochlorococcus growth and mortality rates estimated from the diel cell cycle phase variation as a function of depth for each studied site

explained by the differences in the ecophysiological characteristics of the dominant Prochlorococcus population in the surface layer. If we plot the Prochlorococcus growth rates from the 4 experiments as a function of the percentage of photosynthetically active radiation (PAR) transmitted to the corresponding depth, we find that the maximum Prochlorococcus growth rate occurred at $\sim 15 \%$ of the surface irradiance, except at W-EqPac where the maximum Prochlorococcus growth rate was at the $5 \%$ light level. This physiological difference may be evidence of different Prochlorococcus species. The integrated growth rates for the upper $150 \mathrm{~m}$ of the water column were quite similar at all locations (Table 1 ) and corresponded to previous estimates at $140^{\circ} \mathrm{W}$ (Vaulot et al. 1995, Binder et al. 1996). Together, high growth rate and abundance in these oligotrophic waters (Table 1) imply that Prochlorococcus was not nutrient-limited at the oligotrophic W-EqPac Station or at Station ALOHA.

The mortality rates calculated from Eqs. (3) \& (4) give the total loss of Prochlorococcus biomass. The estimated total mortality rates of Prochlorococcus essentially matched growth rates at most depths at each station (Fig 3). However, this 'match' is only a reflection of relatively constant cell numbers at the same time of the day because our mortality estimation is related to the growth rate estimates. Although protozoan grazing is the most important fate of Prochlorococcus (Landry et al. 1995, Liu H. et al. 1995), other losses such as lysis due to virus infection could be significant, especially in the high temperature, high solar irradiance tropical waters (Cottrell \& Suttle 1995). It is estimated that an average of $3 \%$ of Synechococcus populations, a close relative of Prochlorococcus, are lysed daily by viruses (Suttle 1994). Fuhrman \& Noble (1995) found approximately equal significance of viral lysis and protist grazing for bacterial mortality in coastal waters.

Because of the phased growth and balanced grazing, the abundance of Prochlorococcus in the water column also varies over a $24 \mathrm{~h}$ period. We obtained the diel pattern of cell concentration and all fluorescence and light scatter parameters for Prochlorococcus from each station. Although there was noise at some individual depths that was probably due to the movement of the research vessel and horizontal variation or patchiness 


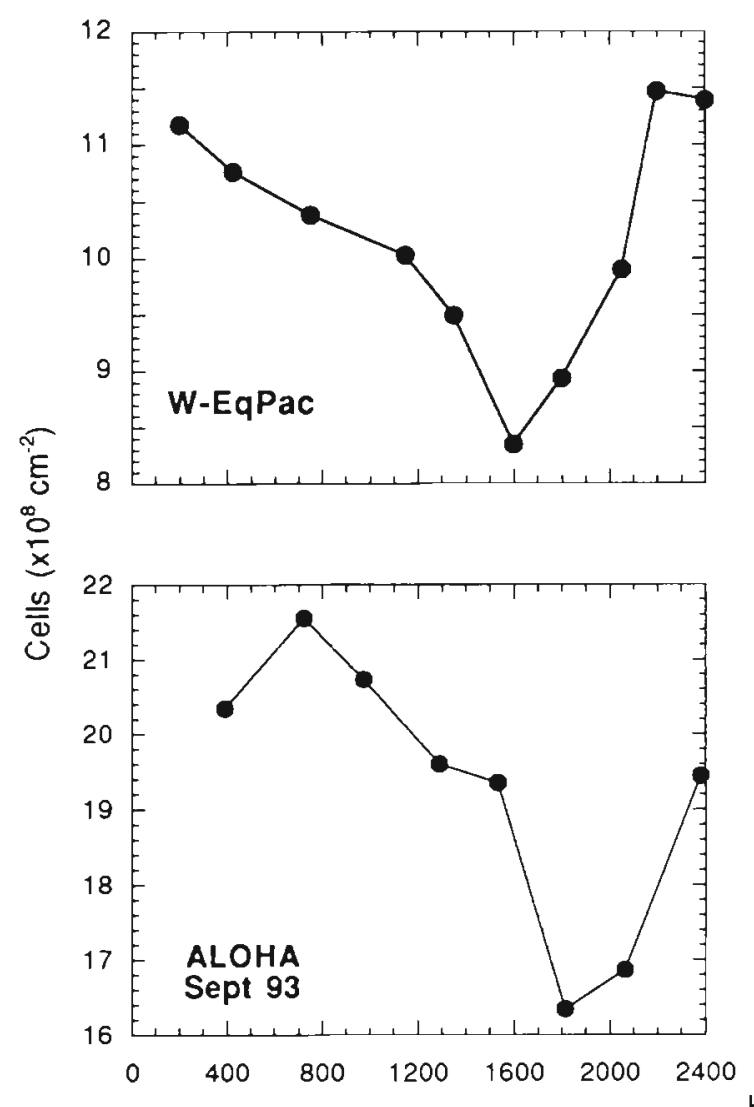

Hour
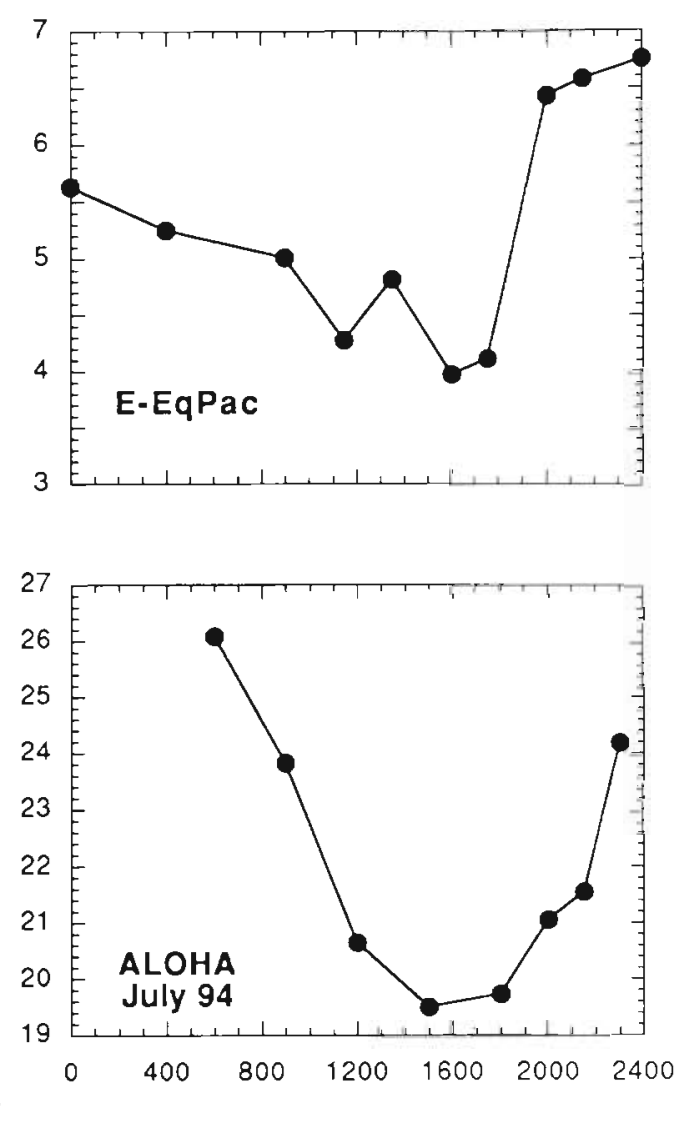

Fig. 4. Daily variation of depth-integrated Prochlorococcus cell concentrations for all sampling sites

in the vicinity of the study area, the variation of the depth-integrated Prochlorococcus cell concentration through the $24 \mathrm{~h}$ sampling period showed the same pattern at all stations (Fig. 4). The maximum cell concentration occurred around midnight. Cell concentration then decreased and began to increase again between 16:00 and 18:00 h. Although the integration over the water column mixed up the 2 to 3 h difference in cell cycle progress, it clearly indicated synchronized growth of Prochlorococcus. If the mortality of Prochlorococcus caused by microzooplankton grazing and other losses is constant throughout the day, the ratio of the minimum to maximum cell concentration in a day can be predicted by a simple model (Fig. 5). When Prochlorococcus grow at 1 doubling $\mathrm{d}^{-1}$ and growth is balanced by total losses, the ratio of the minimum to maximum would be 0.6 , if we assume the cell division occurred only from 19:00 h through midnight. This ratio is inversely related to the length of the time period that Prochlorococcus cells are engaged in replication. For example, if cell division started $2 \mathrm{~h}$ earlier or later, the ratio of the minimum to maximum of cell concentration would be 0.64 or 0.57 , respectively. However, the fact that grazing is probably not constant

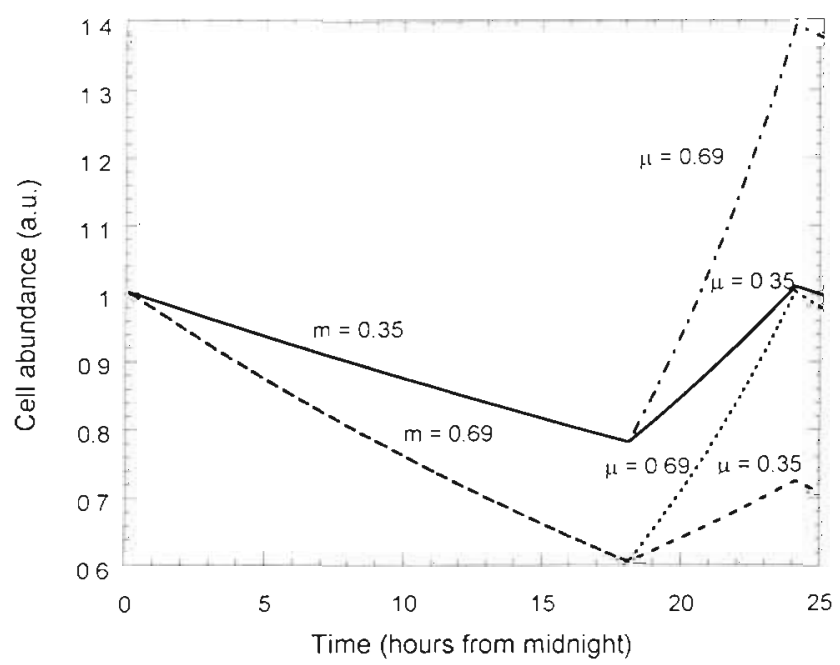

Fig. 5. A simple model for predicting the diel variation in Prochlorococcus cell concentrations based on phased cell division ( $\mu$ is constant from 18:00 h through 24:00 h, and equal to 0 during other times of the day) and constant mortality rates ( $m$ is constant throughout the day). The $\mu\left(\mathrm{d}^{-1}\right)$ and $m\left(\mathrm{~d}^{-1}\right)$ shown in the figure are mean growth and mortality rates over a $24 \mathrm{~h}$ period. The instantaneous growth rate over the $6 \mathrm{~h}$ growth period is actually much higher The rates of 0.69 and $0.35 \mathrm{~d}^{-1}$ represent 1 and 0.5 doublings $\mathrm{d}^{-1}$, respectively 
throughout the day (Christoffersen 1994, Liu H. et al. 1995) makes the diel variation of Prochlorococcus abundance less predictable. Assuming no cell division occurred prior to $16: 00 \mathrm{~h}$ (18:00 h for Station ALOHA), the mortality rates of Prochlorococcus in the no-replication period (midnight to 16:00 h for EqPac and 03:00 to $18: 00 \mathrm{~h}$ for Station ALOHA) were calculated from the decrease in cell concentrations during this period (Fig. 4). Prochlorococcus mortality rates during the time period of cell replication were then calculated from the difference between the observed increase in cell number and the determined growth rates (Table 1). Calculated Prochlorococcus mortality rates were $0.44,0.52,0.37$ and $0.45 \mathrm{~d}^{-1}$ for the no-division period and $0.90,0.21,0.57$ and $0.75 \mathrm{~d}^{-1}$ during the division period for W-EqPac, E-EqPac, ALOHA Sept 93 and ALOHA July 94, respectively. Thus, it appears that Prochlorococcus mortality rate were higher during the time of cell replication, except at the E-EqPac. The mechanisms behind these differences are unclear, but may be related to the feeding rhythms of heterotrophic nanoflagellates (Wikner et al. 1990, Christoffersen 1994). The replication pattern of Prochlorococcus, with rapid cell division from dawn through midnight, may lead to increased grazing activity. An alternative explanation may be that rather than changing their grazing activities, phagotrophic protists control the abundance of picoplankton partly by preferentially removing dividing cells (Sherr et al. 1992). Accurate estimates of diel variation in mortality rate require more frequent sampling and depth-specific computation.

Using a cellular carbon content of Prochlorococcus of $53 \mathrm{fg} \mathrm{C}$ cell $^{-1}$ (Campbell et al. 1994), we estimated that the daily integrated production rate of Prochlorococcus was 409 and $183 \mathrm{mg} \mathrm{C} \mathrm{m} \mathrm{Cd}^{-1}$ at W-EqPac and E-EqPac, respectively (Table 1). The total net primary production at the same stations measured by the ${ }^{14} \mathrm{C}$ method on the same day of our sampling was 670 and $1330 \mathrm{mg} \mathrm{C} \mathrm{m}^{-2} \mathrm{~d}^{-1}$, respectively (data provided by A. Le Bouteiller). This converts to 1039 and $2062 \mathrm{mg} \mathrm{C} \mathrm{m}^{-2}$ $\mathrm{d}^{-1}$ of gross carbon production using the conversion factor of 1.55 determined by Bender et al. (1992). Since our estimation of Prochlorococcus production rate is closer to gross production (Liu H. et al. 1995, Vaulot et al. 1995), we conclude that Prochlorococcus accounted for up to $39 \%$ of total gross primary production at the oligotrophic W-EqPac Station, but only $9 \%$ at the relatively nutrient-rich E-EqPac. The contribution of Prochlorococcus to total gross primary production at Station ALOHA was much higher due to its extremely high abundance. The depth-integrated concentrations of Prochlorococcus at Station ALOHA were more than 2 orders of magnitude higher that those of Synechococcus and picoeucaryotes (Campbell \& Vaulot
1993). We calculate that Prochlorococcus accounted for $74 \%$ of total gross primary production in September 1993 and $82 \%$ in July 1994 . This agrees with the percentage of chlorophyll and carbon biomass represented by Prochlorococcus at Station ALOHA (Letelier et al. 1993, Campbell et al. 1994).

Primary production measured with the ${ }^{14} \mathrm{C}$ method actually represents something between net and gross carbon production (Bender et al. 1987, Grande et al. 1989, Kiddon et al. 1995, Langdon et al. 1995). Bender et al. (1992) scaled the difference between ${ }^{14} \mathrm{C}$ production and gross carbon production through 2 different approaches. We chose to use the factor determined from the relationship between dawn-to-dusk ${ }^{14} \mathrm{C}$ production and ${ }^{18} \mathrm{O}$ production rather than the one determined from estimating ${ }^{14} \mathrm{C}$ loss from the difference between dawn-to-dusk and $24 \mathrm{~h}{ }^{14} \mathrm{C}$ productivities because we believe that the loss of fixed carbon to DOC or to small particles not retained during filtration is significant and the respiration rate may be greater during the daytime as pointed out by Bender et al. (1992). The average loss of carbon during the night was $21 \%$ of the daytime production in the ${ }^{14} \mathrm{C}$ measurement during the FLUPAC cruise (A. Le Bouteiller pers. comm.). This closely matches the $20 \%$ average obtained by Bender et al. (1992) in the North Atlantic Ocean and suggests that our approximation is suitable. Applying the ratio between net and gross production (0.4; Kiddon et al. 1995) to scale the ${ }^{14} \mathrm{C}$ production to gross carbon production (e.g. Vaulot et al. 1995) will overestimate the total gross production.

The fact that the contribution of Prochlorococcus to gross primary production is highest at Station ALOHA, followed by W-EqPac, and lowest at E-EqPac, leads us to conclude that the contribution of Prochlorococcus to the total gross primary production increases as the euphotic zone of the water column becomes more oligotrophic. Evidence to suggest that Station ALOHA in the subtropical North Pacific gyre is more oligotrophic than W-EqPac is based on nutrient and primary production data. First, the nitracline, which is defined as the shallowest depth of first appearance of $0.1 \mu \mathrm{M}$ $\mathrm{NO}_{2}+\mathrm{NO}_{3}$, is deeper at Station ALOHA than at WEqPac (Table 1). Second, the depth-integrated $\mathrm{NO}_{2}+\mathrm{NO}_{3}$ in the upper $150 \mathrm{~m}$ of the water column was $57 \mu \mathrm{mol} \mathrm{cm} \mathrm{cm}^{-2}$ at $\mathrm{W}$-EqPac, but only 2.8 to $5.3 \mu \mathrm{mol} \mathrm{\textrm {cm } ^ { - 2 }}$ at Station ALOHA. Third, the depth-integrated chlorophyll concentration and primary production at $\mathrm{W}$ EqPac was higher than that at Station ALOHA (Table 1).

Our study shows that Prochlorococcus can grow quite rapidly (up to 1 doubling $\mathrm{d}^{-1}$ ) under conditions of relatively low nutrients and irradiance. The small size and adaptability of the picoplankton enable it to take up dissolved nutrients much more efficiently than 
larger organisms (see Fogg 1995). The high growth coupled with high mortality rates at all sites studied suggests that Prochlorococcus growth is not severely nutrient-limited in the oligotrophic environment. Its growth rate may be dependent upon rapid cycling of nutrients by protozoan grazing activity. Grazing of protozoa such as phagotrophic flagellates and ciliates not only maintains the picophytoplankton population at a stable level, but also controls picoplankton growth rate by nutrient feedback (Ferrier \& Rassoulzadegan 1991, 1994). Because of the phased cell division and variable yet substantial grazing pressure, the abundance of Prochlorococcus could vary up to 2 -fold depending on the sampling time. Consideration of this diel variation in abundance, as well as daily variations in cell size (Binder et al. 1996) and chlorophyll content (Vaulot \& Marie 1995), is needed in future studies of the dynamics of phytoplankton community structure and primary production

Acknowledgements. We thank R. LeBorgne and Yves Dandonneau for inviting H.L. to participate in the FLUPAC cruise and D. M. Karl and the JGOFS HOT personnel for their continued support of our field experiments at Station ALOHA. We also thank J. Blanchot, Renate Scharek and Karen Selph for assistance in diel sampling. We gratefully acknowledge financial support from the National Science Foundation (OCE 90-15883 to L.C.) and French JGOFS Program EPOPE (travel funds to H.L.). Comments from D. Vaulot, J. Marra, M. R. Landry and 3 anonymous reviewers are most appreciated. This is contribution no. 4174 from the School of Ocean and Earth Science and Technology, University of Hawaii.

\section{LITERATURE CITED}

Banse K (1992) Grazing, temporal changes of phytoplankton concentrations, and the microbial loop in the open sea. In Falkowski PG, Woodhead AD (eds) Primary production and biogeochemical cycles in the sea. Plenum Press, New York, p 409-440

Barber RT, Chavez FP (1983) Biological consequences of El Niño. Science 222:1203-1210

Bender M, Ducklow H, Kiddon J, Marra J, Martin J (1992) The carbon balance during the 1989 spring bloom in the North Atlantic Ocean, $47^{\circ} \mathrm{N}, 20^{\circ} \mathrm{W}$. Deep Sea Res 39 $1707-1725$

Bender M, Grande KD, Johnson K, Marra J, Williams PJLeB, Sieburth J, Pilson $M$, Langdon $C$, Hitchcock $G$, Orchardo J, Hunt C, Donaghay P, Heinemann K (1987) A comparison of four methods for the determination of planktonic community metabolism. Limnol Oceanogr 32:1085-1098

Binder BJ, Chisholm SW, Olson RJ, Frankel SL, Worden AZ (1996) Dynamics of pico-phytoplankton, ultra-phytoplankton, and bacteria in the central equatorial Pacific. Deep Sea Res II 43:907-931

Campbell L, Liu H, Nolla HA, Vaulot D (1997) Annual variablity of phytoplankton and bacteria in the subtropical North Pacific Ocean at Station ALOHA during the 1991-1994 ENSO event. Deep Sea Res (in press)

Campbell L, Nolla HA, Vaulot D (1994) The importance of Prochlorococcus to community structure in the central
North Pacific Ocean. Limnol Oceanogr 39:954-961

Campbell L, Vaulot D (1993) Photosynthetic picoplankton community structure in the subtropical North Pacific Ocean near Hawail (station ALOHA). Deep Sea Res 40: 2043-2060

Carpenter EJ, Chang J (1988) Species-specific phytoplankton growth rates via diel DNA synthesis cycles. I. Concept of the method. Mar Ecol Prog Ser 32:139-148

Christoffersen K (1994) Variations of feeding activities of heterotrophic nanoflagellates on picoplankton. Mar Microb Food Webs 8:111-123

Cooper S. Helmstetter CE (1968) Chromosome replication and the division cycle of Escherichia coli B/r. J Mol Biol 31. $519-540$

Cottrell MT, Suttle CA (1995) Dynamics of a lytic virus infecting the photosynthetic picoflagellate Micromonas pusilla. Limnol Oceanogr 40:730-739

Cullen JJ, Lewis MR, Davis CO, Barber RT (1992) Photosynthetic characteristics and estimated growth rates indicate grazing is the proximate control of primary production in the equatorial Pacific. J Geophys Res 97:639-654

Ferrier C. Rassoulzadegan F (1991) Density-dependent effects of protozoans on specific growth rates in pico- and nanoplanktonic assemblages. Limnol Oceanogr 36: $657-669$

Ferrier C, Rassoulzadegan F (1994) Seasonal impact of the microzooplankton on pico- and nanoplankton growth rates in the northwest Mediterranean Sea. Mar Ecol Prog Ser 108:283-294

Fitzwater SE, Knauer GA, Martin JH (1982) Metal contamination and its eftect on primary production measurements. Limnol Oceanogr 27:544-551

Fogg GE (1995) Some comments on picoplankton and its importance in the pelagic ecosystem. Aquat Microb Ecol 9:33-39

Fuhrman JA, McManus GB (1984) Do bacteria-sized marine eukaryotes consume significant bacterial production? Science 224:1257-1260

Fuhrman JA, Noble RT (1995) Viruses and protists cause similar bacterial mortality in coastal seawater. Limnol Oceanogr 40:1236-1242

Grande KD, Williams PJLeB, Marra J, Purdie DA, Heinemann K. Eppley RW, Bender ML (1989) Primary production in the North Pacific gyre: a comparison of rates determined by the ${ }^{14} \mathrm{C}, \mathrm{O}_{2}$ concentration and ${ }^{18} \mathrm{O}$ methods. Deep Sea Res 36:1621-1634

Karl DM, Letelier RM, Hebel D, Tupas L, Dore J, Christian J, Winn C (1995) Ecosystem changes in the North Pacific subtropical gyre attributed to the 1991-1992 El Niño. Nature 373:230-234

Kiddon J, Bender ML, Marra J (1995) Production and respiration in the 1989 North Atlantic spring bloom: an analysis of irradiance-dependent changes. Deep Sea Res 42:553-576

Landry MR, Hassett RP (1982) Estimating the grazing impact of marine micro-zooplankton. Mar Biol 67:283-288

Landry MR, Kirshtein J, Constantinou J (1995) A refined dilution technique for measuring the community grazing impact of microzooplankton, with experimental test in the central equatorial Pacific. Mar Ecol Prog Ser 120:5.3-63

Langdon C, Marra J, Knudson C (1995) Measurements of net and gross $\mathrm{O}_{2}$ production, dark $\mathrm{O}_{2}$ respiration, and ${ }^{14} \mathrm{C}$ assimilation at the Marine Light Mixed Layers site $\left(59^{\circ} \mathrm{N}\right.$, $21^{\circ} \mathrm{W}$ ) in the northeast Atlantic Ocean. J Geophys Res 100:6645-6653

Laws EA, DiTullio GR, Carder KL, Betzer PR, Hawes S (1990) Primary production in the deep blue sea. Deep Sea Res $37: 715-730$ 
Le Borgne $R$, Brunet $C$, Eldin $G$, Radenac $M H$, Rodier $M$ (1995) Campagne océanographique FLUPAC à bord du N.O. I'ATALANTE 23 septembre au 29 octobre 1994. Recueil des données, Tome 1. Centre de Nouméa, Orstom

Le Bouteiller A, Blanchot J, Rodier M (1992) Size distribution patterns of phytoplankton in the western Pacific: towards a generalization for the tropical open ocean. Deep Sea Res 39:805-823

Letelier RM, Bidigare RR, Hebel DV, Ondrusek M, Winn C, Karl DM (1993) Temporal variability of phytoplankton community structure based on pigment analysis. Limnol Oceanogr 38:1420-1437

LI WKW (1995) Composition of ultraphytoplankton in the central North Atlantic. Mar Ecol Prog Ser 122:1-8

Li WKW, Subba Rao DV, Harrison WG, Smith JC, Cullen JJ, Irwin B, Platt T (1983) Autotrophic picoplankton in the tropical ocean. Science 219:292-295

Liu H, Campbell L, Landry MR (1995) Growth and mortality rates of Prochlorococcus and Synechococcus measured with a selective inhibitor technique. Mar Ecol Prog Ser $116: 277-287$

Liu WT, Tang W, Fu LL (1995) Recent warming event in the Pacific may be an E] Niño. Eos 76:429

McDuff RE, Chisholm SW (1982) The calculation of in situ growth rates of phytoplankton populations from fractions of cells undergoing mitosis: a clarification. Limnol Oceanogr 27:783-788

McManus GB (1995) Phytoplankton abundance and pigment changes during simulated in situ dilution experiments in estuarine waters: possible artifacts caused by algal light adaptation. J Plankton Res 17:1705-1716

Peña MA, Lewis MR, Harrison WG (1990) Primary productivity and size structure of phytoplankton biomass on a tran-

Responsible Subject Editor: S. Chisholm, Cambridge, Massachusetts, USA sect of the equator at $135^{\circ} \mathrm{W}$ in the Pacific Ocean. Deep Sea Res 37:295-315

Platt T, Rao DVS, Irwin B (1983) Photosynthesis of picoplankton in the oligotrophic ocean. Nature 301:702-704

Sherr BF, Sherr EB, McDaniel J (1992) Effect of protistan grazing on the frequency of dividing cells in bacterioplankton assemblages. Appl Environ Microbiol 58: $2381-2385$

Suttle CA (1994) The signuficance of viruses to mortality in aquatic microbial communities. Microb Ecol 28:237-244

Vaulot D (1989) CYTOPC: processing software for flow cytometric data. Signal \& Noise $2: 8$

Vaulot D (1992) Estimate of phytoplankton division rates by the mitotic index method: the $f_{\mathrm{max}}$ approach revisited Limnol Oceanogr 37:644-649

Vaulot D (1995) The cell cycle of phytoplankton: coupling cell growth to population growth. In: Joint IR (ed) Molecular ecology of aquatic microbes. Springer-Verlag, Berlin, p 303-322

Vaulot D, Marie D (1995) Daily variablity of picoplankton in the equatorial Pacific during the OLIPAC cruise. In: First JGOFS international scientific symposium, Book of abstracts. Scientific Committee on Oceanic Research, ICSU, Villefranche-sur-Mer, p 44

Vaulot D, Marie D, Olson RJ, Chisholm SW (1995) Growth of Prochlorococcus, a photosynthetic prokaryote, in the Equatorial Pacific Ocean. Science 268:1480-1482

Vaulot D, Partensky F (1992) Cell cycle distributions of prochlorophytes in the north western Mediterranean Sea. Deep Sea Res 39:727-742

Wikner J, Rassoulzadegan F, Hagström $\AA$ (1990) Periodic bacterivore activity balances bacterial growth in the marine environment. Limnol Oceanogr 35:313-324

Manuscript first received: June 17, 1996

Revised version accepted: October 8, 1996 